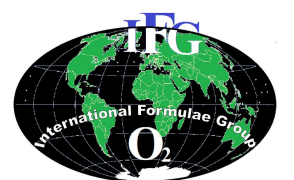

\title{
Distribution of Polycyclic Aromatic Hydrocarbons (PAHs) in a tropical coastal lagoon (Grand-Lahou lagoon, Côte d'Ivoire)
}

\author{
R. KOUAKOU ${ }^{2}$, A.M. KOUASSI ${ }^{1 *}$, E. Kouassi KWA-KOFFI ${ }^{2}$, U.P. GNONSORO ${ }^{2}$ \\ et A. TROKOUREY ${ }^{2}$ \\ ${ }^{1}$ Centre de Recherches Océanologiques BP V18 Abidjan, Côte d'Ivoire. \\ ${ }^{2}$ Université Felix Houphouët Boigny, Côte d'Ivoire. \\ "Corresponding author; E-mail: aka.marcel.kouassi@gmail.com; Tel (225) 07738311; Fax (225) 21351155.
}

\begin{abstract}
The distribution of 8 polycyclic aromatic hydrocarbons (PAHs) in the surface sediments of the GrandLahou lagoon (Côte d'Ivoire) was investigated using a high performance liquid chromatography (HPLC). The total concentrations of PAHs were between 1.55 and $437.52 \mu \mathrm{g} / \mathrm{g}$ in the dry season. Pyrene, benzo (b) fluoranthene and fluoranthene have the highest concentrations. In the rainy season, the total PAHs concentrations varied between 46.35 and $1222.73 \mu \mathrm{g} / \mathrm{g}$. Pyrene, benzo (a) pyrene and benzo (a) anthracene were the most present in the sediments of the lagoon of Grand-Lahou during the wet season. Possible sources of PAHs in the lagoon of Grand-Lahou are oil and fuel spills from ships and fishing boats, combustion of waste, domestic waste disposal and especially the production of charcoal on the Grand-Lahou lagoon shores. A clear dominance of high molecular weight (HMW) PAHs (pyrene, Benzo (k) fluoranthene, Benzo (a) pyrene, indeno (1,2,3-cd) pyrilène, Benzo ( $\mathrm{g}, \mathrm{h}, \mathrm{i})$ pyrilene, Benzo (a) anthracene , Benzo (b) fluoranthene) was observed compared to low molecular weight (LMW) PAHs (fluoranthene).
\end{abstract}

(C) 2015 International Formulae Group. All rights reserved.

Keywords: Polycyclic Aromatic Hydrocarbon (PAH), coastal lagoon, pollution, West Africa.

\section{INTRODUCTION}

Polycyclic aromatic hydrocarbons (PAHs) are neutral nonpolar organic compounds, consisting of at least two aromatic rings containing only carbon and hydrogen atoms. They are mainly formed during the incomplete combustion of organic matter (pyrolitic sources) (Eisler, 1987; Baek et al., 1991) and during the slow maturation of the organic matter accumulated in deep sedimentary environments (petrogenic sources) (Wang et al., 2004). These two sources have distinct formation mechanisms that are realized with different kinetics. PAHs from pyrolitic and petrogenic sources exhibit different chemical behaviours and distribution in sediments. In particular, PAHs from pyrolitic processes are more strongly associated to sediments and much more resistant to microbial degradation than PAHs of petrogenic origin. PAHs may also be formed by micro-organisms from biogenic precursors such as di- and tri-terpenes, steroids, pigments or quinones in sediments or recent soils (Wakeham et al., 1980); these precursors may come from terrestrial or 
aquatic biological tissues (plants, animals, bacteria, macro- and micro-algae) (Wang et al., 2004).

PAHs are ubiquitous compounds present in all environmental compartments (atmosphere, water column, biota, sediment, soil). In the aquatic environments, due to their hydrophobic nature, PAHs are mostly adsorbed on the particulate material and are associated to organic matter due to their physicochemical properties. They reach then the aquatic bottom by decantation of particles; thus the sedimentary mass constitutes the major reservoir of hydrophobic compounds (Neff, 1979). For this reason, the sediments are of great interest in the environmental assessment of aquatic ecosystems.

Polycyclic aromatic hydrocarbons are among the most monitored pollutants particularly in shallow coastal areas subject to anthropogenic inputs and natural emissions ( $\mathrm{Li}$ et al., 1998). Accumulation and persistence of PAHs present a risk to human health and the environment, firstly due to their characteristics and also because of the many sources of exposure. PAHs have toxic, mutagenic and carcinogenic properties (Juhsz and Naidu, 2000; Semlali et al., 2012). However, very few studies have been conducted in African tropical coastal lagoons (Soclo et al., 2000; Nyarko et al., 2011; Semlali et al., 2012).

In Côte d'Ivoire, the coastal region is characterized by the presence of many lagoons of which the most important are, from west to east, the Fresco, the Grand Lahou, the Ebrié and the Aby lagoons. These coastal ecosystems play an important role in the reproduction of fish and shrimp, and are irreplaceable habitats for many species of migratory and local birds (Kouassi, 2005). They are also important for the Ivorian economy since they provide suitable areas for fishing, aquaculture, tourism, transport activities, etc. Unfortunately, these lagoons undergo intense human activities (production of charcoal, fisheries, transport ...) susceptible of causing PAHs pollution.

This work aims at studying the distribution of PAHs in superficial sediments of the Grand Lahou lagoon (Côte d'Ivoire).

\section{MATERIALS AND METHODS}

\section{Study site}

The Grand-Lahou ecosystem (Figure 1), with an area of about $190 \mathrm{~km}^{2}$, is located between $5^{\circ} 25^{\prime} \mathrm{W}$ and $5^{\circ} 10^{\prime} \mathrm{N}$. It is actually a complex of four small lagoons (Figure 1) comprising:

- The Tagba lagoon located at the east side, with a mean depth of $3 \mathrm{~m}$. It covers an area of approximately $57 \mathrm{~km}^{2}$. However, there are some areas (close to the inlet) as deep as 8 m. It communicates with the Atlantic Ocean and receives the Bandama River;

- The Mackey lagoon, with up to $2 \mathrm{~m}$ depth, is the shallowest. It receives waters from the Gô and Boubo Rivers, has an area of about $28 \mathrm{~km}^{2}$ and is connected to the Tagba and Tadjo lagoons;

- The Tadjo lagoon with an area of 90 $\mathrm{km}^{2}$, is the largest. It is strongly influenced by the Boubo river;

- The Niouzoumou lagoon directly communicates with the Tadjo lagoon. It is parallel to the barrier beach. It has an area of $15 \mathrm{~km}^{2}$ and a maximum depth of $3 \mathrm{~m}$. It connects to the Tagba lagoon by an artificial channel called Groguida canal.

The Grand-Lahou lagoon is fed by the Bandama and the Boubo Rivers. The Bandama River has a total length of $1,050 \mathrm{~km}$ (Laé, 1982), a total catchment area of 97,000 $\mathrm{km}^{2}$ and an annual average rate of about 172 $\mathrm{m}^{3} / \mathrm{s}$ (Girard et al., 1971). According to Durand and Chantraine (1982), the Bandama River alone contributes to $95 \%$ of the continental inputs. The Boubo is characterized by two flood seasons with an average flow of $29.10 \mathrm{~m}^{3} / \mathrm{s}$ in June and about $16 \mathrm{~m}^{3} / \mathrm{s}$ in November. Between the two flood periods, there is an inter-flood which usually occurred during the month of August with an average 
flow of $13.01 \mathrm{~m}^{3} / \mathrm{s}$. The Grand-Lahou lagoon also directly receives rainfall which represents $5 \%$ of the continental inputs (Durand and Chantraine, 1982). It is connected to the Atlantic Ocean by a channel (Hie, 1986) whose width is between 150 and $200 \mathrm{~m}$ (Abe et al., 1993). The oceanic waters volume penetrating in the lagoon has not been assessed.

The Grand-Lahou lagoon system is supplied with sediment from rivers, streams and runoff. The sediment is composed of sand and silt grain from 1.6 to $45.10^{-6} \mathrm{~m}$. The channels, with depths between 3 and $5 \mathrm{~m}$ are covered with vases and clay to fine grains less than median $5.10^{-6} \mathrm{~m}$ (Abe et al., 1993). The water content of these vases is high: 200 to $700 \%$ by weight of dry sediment. Minerals are found in decreasing order of importance, kaolinite, illite and montmorillonite swelling illite inter-layered; the calcite content of 0 to $15 \%$ depending on the presence of shells and mollusks. Pyrite is present in vases rich in organic matter. The organic matter is relatively abundant in fine sediments found in channels and ditches where its accumulation is related to the hydrodynamics, and in areas with high inputs of continental plant or planktonic debris. The concentrations are between 0 and $1 \%$ in sandy sediments and exceed $20 \%$ in vases (Abe et al., 1993).

\section{Sampling}

The sediment sampling campaigns were conducted during the dry and wet season in ten stations (Figure 1) spreaded along the Grand-Lahou lagoon system. Sediment samples were collected using a metal tipper, packaged in aluminum foil and transported in an ice box to the laboratory. At the laboratory, the sediment samples were dried on aluminum foil at room temperature and stored in a refrigerator at $4{ }^{\circ} \mathrm{C}$ for extraction.

\section{Extraction and purification}

$25 \mathrm{~g}$ of sediment previously dried in ambient air, crushed in a mortar and sieved were weighed and introduced in a flask. $50 \mathrm{ml}$ of dichloromethane are then added to the sediment and mixed vigorously overnight with a mechanical stirrer. The mixture was filtered through a filter paper and placed in a round bottom flask. The filtrate was then evaporated to dryness on a rotary evaporator with a water bath to a temperature below 30 ${ }^{\circ} \mathrm{C}$ to minimize loss of volatile components. The substrate is recovered with $10 \mathrm{ml}$ of methanol for the purification phase.

The extracts are purified by conditioning on a $\mathrm{C} 18$ cartridge which is previously activated with $10 \mathrm{ml}$ methanol. The cartridge must not be dried for more than 30 seconds before the next step. All of the prepared sample is passed through the cartridge and is left dripped. The eluate is collected in a vial for analysis by HPLC.

\section{HAP analysis}

Determination of PAHs was carried out using a Shimadzu liquid chromatograph LC20AT Model equipped with a getter Model DGU-20A5, a SHIMADZU UV/Visible detector, model SPD-20A and a SIL-20A injector model.

The device allows an ultraviolet detection at variable wavelengths and it allows to obtain gradients of solvent using a pump. Also, with software (LC - solution), it can control the whole system and ensure the data acquisition. The separation was performed on an analytical column type VPODS, $154 \mathrm{~mm}$ length and $4.6 \mathrm{~mm}$ inner diameter with a degree of pre-column of $10 \mathrm{x}$ $4.6 \mathrm{~mm}$.

The mobile phase consists of a mixture of acetonitrile (A) and ultrapure water (E) (acetonitrile/water (80/20)) with a flow rate of $0.5 \mathrm{~mL} / \mathrm{min}$ and the column temperature was $40{ }^{\circ} \mathrm{C}$. The injections were performed with an automatic injector; the injection volume was $20 \mu 1$ and the analysis time was $10 \mathrm{~min}$. 


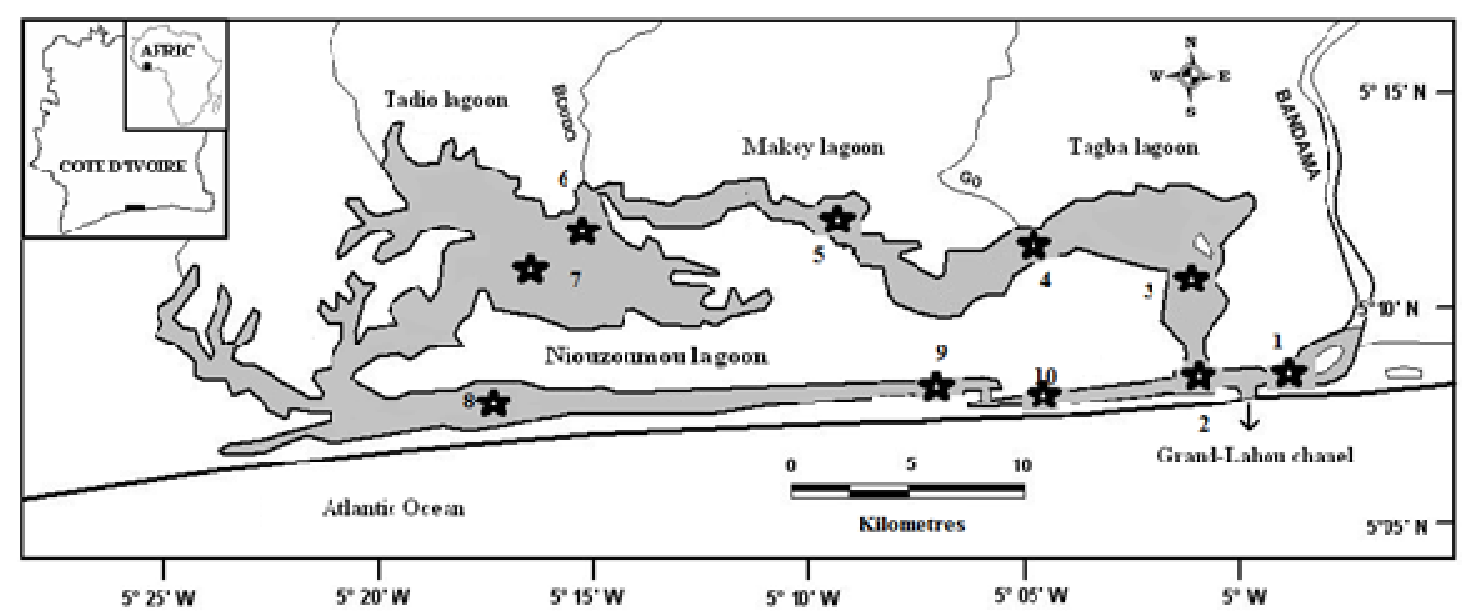

Figure 1: Sampling stations in the Grand-Lahou lagoon.

\section{RESULTS AND DISCUSSION}

Concentrations of polycyclic aromatic hydrocarbons are displayed in Tables 1 and 2 . A total of eight (8) PAHs compounds were identified in the sediments of the Grand Lahou ecosystem. These are Fluoranthene, Pyrene, Benzo (k) fluoranthene, Benzo (a) pyrene, indeno (1,2,3-cd) pyrilene, Benzo ( $\mathrm{g}, \mathrm{h}, \mathrm{i})$ pyrilene, Benzo (a) anthracene and benzo (b ) fluoranthene.

The average concentrations of PAHs vary from $\mathrm{LD}$ to $105 \mu \mathrm{g} / \mathrm{g}$ for fluoranthene; from $\mathrm{LD}$ to $381.08 \mu \mathrm{g} / \mathrm{g}$; for pyrene; from $\mathrm{LD}$ to $162.87 \mu \mathrm{g} / \mathrm{g}$ for benzo $(\mathrm{k})$ fluoranthene; from LD to $18.70 \mu \mathrm{g} / \mathrm{g}$ for benzo (a) pyrene, from $\mathrm{LD}$ to $6.35 \mu \mathrm{g} / \mathrm{g}$ for indeno $(1,2,3-\mathrm{cd})$ pyrilene; from LD to $1.27 \mu \mathrm{g} / \mathrm{g}$ for benzo ( $\mathrm{g}$, $\mathrm{h}, \mathrm{i})$ pyrilene; from LD to $5.18 \mu \mathrm{g} / \mathrm{g}$ for benzo (a) anthracene and from LD to $10.69 \mu \mathrm{g} / \mathrm{g}$ for benzo (b) fluoranthene.

The sediments of the Grand-Lahou lagoon have relatively high concentrations in PAHs than those of the African lagoons of Chemu, Korle and Kpeshie (Essumang et al., 2009), Cotonou (Soclo et al., 2000) and Bizerte (Trabelsi and Driss, 2005) (Table 2). Data obtained from these works are also significantly higher than other coastal ecosystems from other parts of the world (Table 3).
The total concentration of PAHs was between 1.55 and $437.52 \mu \mathrm{g} / \mathrm{g}$ in the dry season. Pyrene, benzo (b) fluoranthene and fluoranthene have the highest concentrations. In the rainy season, the total PAHs concentrations varied between 46.35 and $1222.73 \mu \mathrm{g} / \mathrm{g}$. Pyrene, benzo (a) pyrene and benzo (a) anthracene were the most present in the sediments of the lagoon of Grand-Lahou during the wet season.

Apart from the stations 9 and 10 which have high concentrations of benzo (a) anthracene, stations 1, 2, 3, 4 and 5 are more contaminated with PAHs during the two hydroclimatic seasons (Figures 2 and 3 ). These stations are located in the area of the lagoon characterized by the influence of the freshwater (the Boubo and the Bandama rivers) inputs and by intense agricultural activities leading to deforestation and charcoal production. In Station 1 , is regularly discharged the ferry engine motor oil that carries the local populations from one bank to another. On the contrary, stations 6, 7, 8, 9 and 10 are less contaminated and are located in the sector of the lagoon under the oceanic influence. 
Table 1: Concentrations of PAHs $(\mu \mathrm{g} / \mathrm{g})$ in sediments samples collected in the Grand-Lahou lagoon during the dry season.

\begin{tabular}{lcccccccccc}
\hline & St 1 & St 2 & St 3 & St 4 & St 5 & St 6 & St 7 & St 8 & St 9 & St 10 \\
\hline & & \multicolumn{7}{c}{ Concentration $(\boldsymbol{\mu g} / \mathbf{g})$} \\
\hline Fluoranthene & LD & 0,92 & 9,52 & 31,39 & 105,84 & LD. & LD. & LD & LD & LD \\
Pyrene & LD & 25,04 & LD & 381,08 & LD & 6,21 & 2,02 & 2,19 & LD & LD \\
Benzo(k) fluoranthene & LD & LD & 162,87 & LD & LD & LD & LD. & 0,69 & LD & 0,46 \\
Benzo(a)pyrene & 0,96 & 13,72 & LD & 18,70 & 12,10 & LD & 0,73 & LD & 1,05 & LD \\
Indéno(1,2,3-cd) & LD & LD & LD & 6,35 & LD & LD & 0,36 & LD & 2,83 & LD \\
pyrilene & & & & & & & & & & \\
Benzo(g,h,i)pyrilene & 0,48 & 1,27 & LD & LD & LD & LD & LD & LD & LD & LD \\
Benzo(a) anthracene & LD & 3,66 & LD & LD & LD & 0,25 & LD & LD & LD & 5,18 \\
Benzo(b) fluoranthene & 0,11 & 4,48 & 10,69 & LD & LD & 0,02 & 0,16 & 0,12 & LD & LD \\
Total HAPs & $\mathbf{1 , 5 5}$ & $\mathbf{4 9 , 0 9}$ & $\mathbf{1 8 3 , 0 8}$ & $\mathbf{4 3 7 , 5 2}$ & $\mathbf{1 1 7 , 9 4}$ & $\mathbf{6 , 4 8}$ & $\mathbf{3 , 2 7}$ & $\mathbf{3 , 0 0}$ & $\mathbf{3 , 8 8}$ & $\mathbf{5 , 6 4}$ \\
\hline
\end{tabular}

Table 2: Concentrations of PAHs $(\mu \mathrm{g} / \mathrm{g})$ in sediments samples collected in the Grand-Lahou lagoon during the wet season.

\begin{tabular}{llllllllllll}
\hline & St 1 & St 2 & St 3 & St 4 & St 5 & St 6 & St 7 & St 8 & St 9 & St 10 \\
\hline & & & \multicolumn{7}{c}{ Concentration $(\boldsymbol{\mu g} / \mathbf{g})$} \\
\hline Fluoranthene & LD & LD & LD & LD & LD & LD & LD & LD & LD & LD \\
Pyrene & 227,86 & 249,40 & 33,06 & 87,15 & 1021,22 & 46,35 & 57,35 & 192,36 & LD & LD \\
Benzo(k)fluoranthène & 57,33 & LD & LD & 0,09 & LD & LD & LD & LD & LD & 30,05 \\
Benzo(a)pyrene & 226,33 & 24,55 & LD & 13,16 & 153,36 & LD & LD & 4,59 & LD & LD \\
Indeno(1,2,3- & LD & LD & LD & LD & LD & LD & LD & LD & LD & 12,44 \\
cd)pyrilene & & & & & & & & & & \\
Benzo(g,h,i)pyrilene & LD & LD & LD & LD & LD & LD & LD & LD & LD & LD \\
Benzo(a)anthracene & 124,47 & 7,60 & LD & 12,37 & 48,15 & LD & LD & 11,55 & 784,05 & 121,28 \\
Benzo(b)fluoranthene & LD & LD & LD & LD & LD & LD & LD & LD & LD & LD \\
Total HAPs & $\mathbf{6 3 5 , 9 9}$ & $\mathbf{2 8 1 , 5 5}$ & $\mathbf{3 3 , 0 6}$ & $\mathbf{1 1 2 , 7 7}$ & $\mathbf{1 2 2 2 , 7 3}$ & $\mathbf{4 6 , 3 5}$ & $\mathbf{5 7 , 3 5}$ & $\mathbf{2 0 8 , 5 0}$ & $\mathbf{7 8 4 , 0 5}$ & $\mathbf{1 6 3 , 7 8}$ \\
\hline
\end{tabular}


Table 3: Comparison of sediment PAH concentrations ( $\mu \mathrm{g} / \mathrm{g}$ dry wt) measured in this study compared with those in other countries.

\begin{tabular}{lccc}
\hline Location & $\begin{array}{c}\text { Number of PAH } \\
\text { compounds } \\
\text { analyzed }\end{array}$ & $\begin{array}{c}\text { Mean PAHs } \\
\text { values }\end{array}$ & References \\
\hline Gironde Estuary (France) & 17 & $0.0185-4.88$ & Budzinski et al., 1997 \\
Arcachon Bay (France) & 16 & $1.74-8.42$ & Baumard et al., 1998b \\
Barcelona Harbour (Spain) & 16 & $0.0006-0.203$ & Specchiulli et al., 2010 \\
Orbetello lagoon (Italy) & 16 & $0.112-0.628$ & Giuliani et al., 2008 \\
Vietnamese lagoons (Vietnam) & 18 & $0.01-0.55$ & Pavoni et al., 2001 \\
Mediterranean coast (Morocco) & 16 & $\mathrm{Nd}-2.66$ & Khairy et al., 2009 \\
Abu Qir Bay (Egypt) & 16 & $0.083-0.447$ & Trabelsi and Driss (2005) \\
Bizerte lagoon (Tunisia) & 16 & $0.025-1.45$ & Soclo et al., 2000 \\
Cotonou lagoon (Benin) & 14 & $0.0078-0.011$ & Essumang et al., 2009 \\
Chemu (Ghana) & 16 & $0.00-0.009$ & Essumang et al., 2009 \\
Korle (Ghana), & 16 & $0.00162-0.0047$ & Essumang et al., 2009 \\
Kpeshie (Ghana), & 16 & & \\
\hline
\end{tabular}

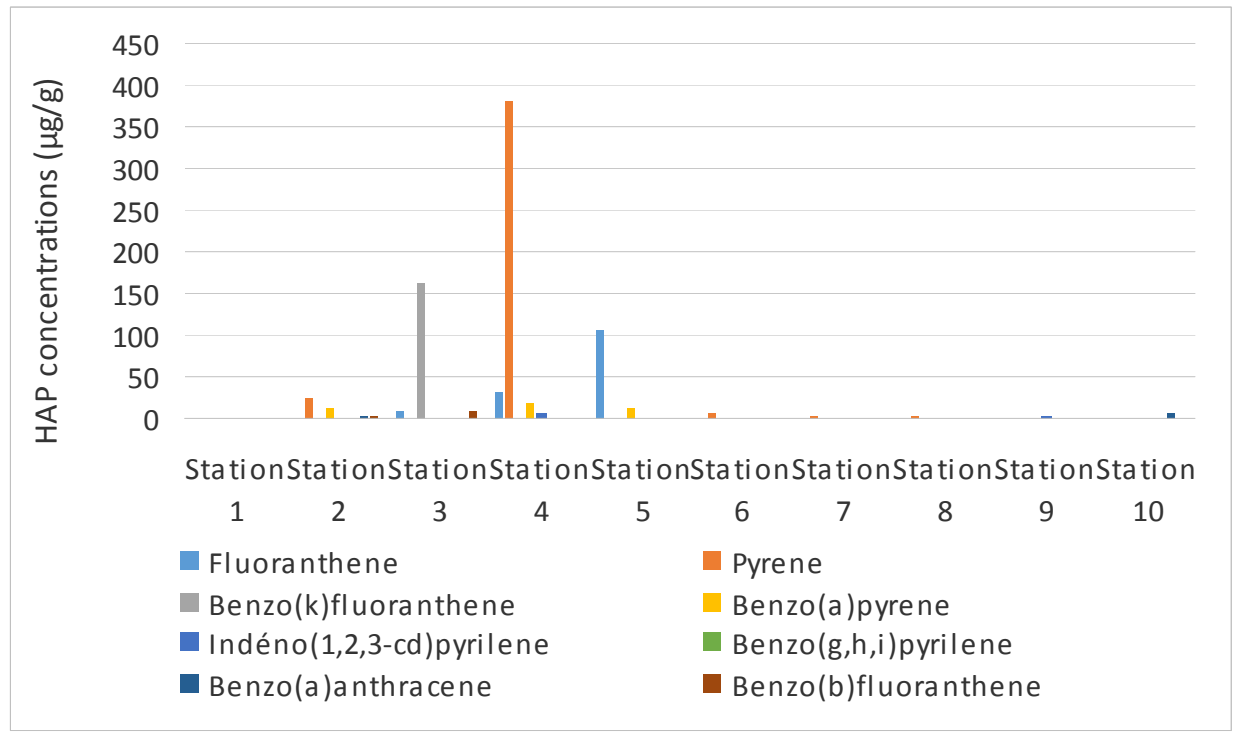

Figure 2: Distribution of PAHs concentrations in surface sediments collected in the Grand-Lahou ecosystem during the dry season. 


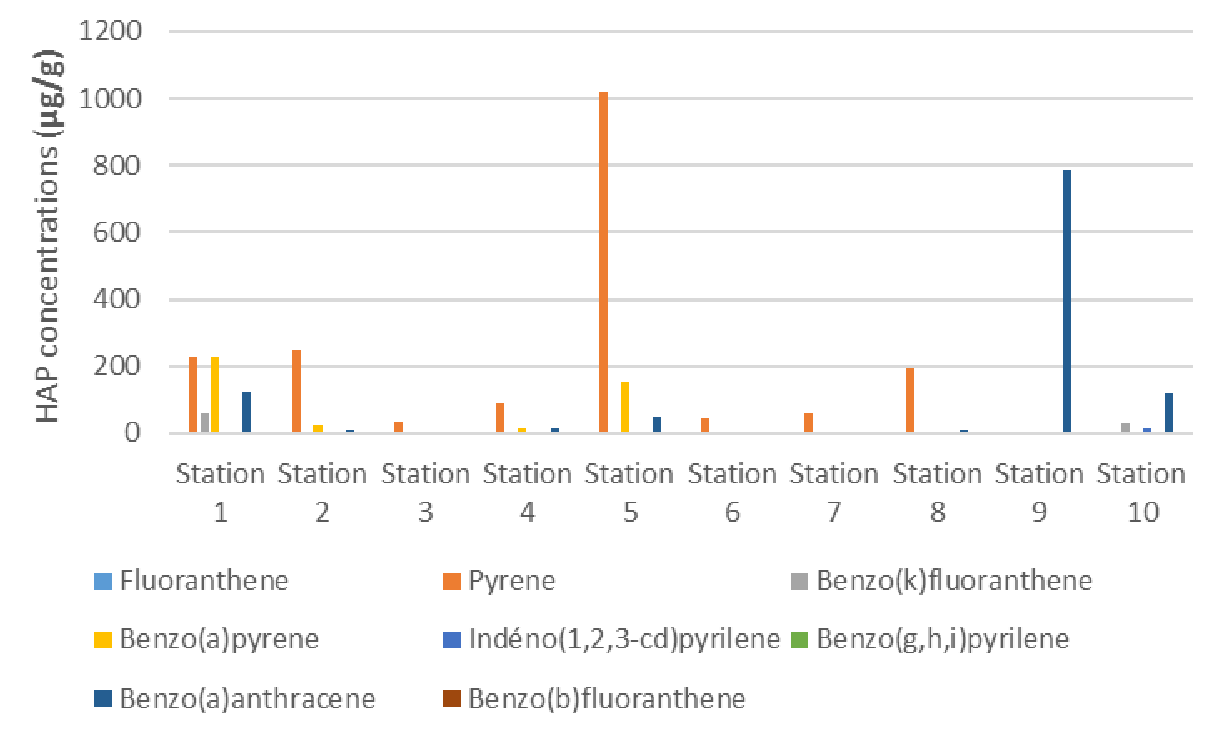

Figure 3: Distribution of PAHs concentrations in surface sediments collected in the Grand-Lahou ecosystem during the wet season.

The presence of PAHs in sediments is an indication of the contamination of the Grand-Lahou lagoon. The sediment compartment is the ultimate repository of hydrophobic contaminants introduced into aquatic environments. It is often referred to as a well or trap of these organic compounds. Thus the sediment provides an essential link in the study of the contamination of the environment by PAHs since it can be used as a record of contamination. It is also necessary to determine the level of PAH in this compartment because it is not only a well of PAHs but it can be a source of the water column contamination in certain circumstances or conditions. Desorption and remobilization of surface material to the water column due to current events or natural/anthropogenic disturbance may increase the bioavailability of PAHs to the biota, mainly benthic biota.

Possible sources of PAHs in the GrandLahou lagoon are oil and fuel spills from ships and fishing boats, waste combustion, domestic wastes disposal and especially the production of charcoal on the Grand-Lahou lagoon shores. High concentrations observed during the rainy season can be attributed to the contribution due to leaching of soil contaminated with PAHs. According Karichkoff et al. (1979), the spatial variations in the PAHs concentrations can also be explained by the heterogeneity of the particle sediment. Indeed, the hydrophobic organic contaminants $(\mathrm{COH})$ are generally associated with the fine fraction of sediments.

A clear dominance of high molecular weight (HMW) PAHs (pyrene, Benzo (k) fluoranthene, Benzo (a) pyrene, indeno (1, 2, 3-cd) pyrilène, Benzo $(\mathrm{g}, \mathrm{h}, \mathrm{i})$ pyrilene, Benzo (a) anthracene, Benzo (b) fluoranthene) is observed. Low molecular weight (LMW) PAHs is only represented by fluoranthene. LMW PAHs are different from HMW PAHs by their number of aromatic rings, and therefore by their molecular weight.

These differences play on their physicochemical and toxicological properties that differ. However, these molecules are poorly soluble, hydrophobic and very slowly degraded; these characteristics are especially true that the compound has a high cycle 
number. Thus, PAHs tend to adsorb to suspended solids and accumulate in sediments as well (specifically on fine particles) in living organisms. It should be noted that the abundance of heavy compounds could indicate contamination from domestic origin, among others, the production of charcoal on the banks of the lagoon. The low presence of LMW hydrocarbons could also be attributed to the high microbial activity in the lagoon environment. According to Lei et al. (2007), microbial activity contributes significantly to the reduction of LMW PAHs in sediments since the PAHs with a small number of aromatic rings are more easily degraded by bacteria in the water column, which reduces the number of molecules that reaches the bottom. Finally, one can note that LMW PAHs being more soluble, they are subject to evaporation and dilution in the water body (Khim et al., 2001).

Molecular ratios, such as phenathrene/anthracene(Phe/An),

Fluoranthene/Pyrene (FL/Pyr), Chrysene/ Benzo(a)anthracene (Chrys/B[a]A) have been proposed for interpreting $\mathrm{PAH}$ composition and identifying possible sources (Soclo et al., 2000; Yunker, 2002; Doong and Lin, 2004). According to Yunker (2002), when the ratio of An /An+Phe $<0.1$, the PAHs were mainly from petroleum contamination, while it is > 0.1 , PAHs were from combustion source. PAHs with $\mathrm{Fl} / \mathrm{Fl}+\mathrm{Pyr}<0.40$ were from petroleum contamination, while a $\mathrm{PAHs}$ with $0.4<\mathrm{Fl} / \mathrm{Fl}+\mathrm{Pyr}<0.5$ were mainly from oil combustion, and $\mathrm{PAHs}$ with $\mathrm{Fl} / \mathrm{Fl}+\mathrm{Pyr}>0.5$ were from combustion of coal, wood and grassed matter (Yunker et al., 2002). Bicego et al. (2006) used the following four PAHs isomer pair ratios to identify possible sources in sediments of the Santos and Sao Vicente Estuary of Sao Paulo (Brazil): An/An+Phe; Fl/Fl+Pyr; B[a]A/B[a]A+chry; IP/IP+BP (IP: Indeno (123-cd) Pyrene; BP: Benzo (e) pyrene). Regarding the $\mathrm{B}[\mathrm{a}] \mathrm{A} / \mathrm{B}[\mathrm{a}] \mathrm{A}+$ chry ratio, PAHs with $0.2<\mathrm{B}[\mathrm{a}] \mathrm{A} / \mathrm{B}[\mathrm{a}] \mathrm{A}+$ chry $<$ 0.35 could be related to a mixed origin. PAHs with $\mathrm{B}[\mathrm{a}] \mathrm{A} / \mathrm{B}[\mathrm{a}] \mathrm{A}+$ chry $<0.2$ were mainly from petroleum contamination, while PAHs with $\mathrm{B}[\mathrm{a}] \mathrm{A} / \mathrm{B}[\mathrm{a}] \mathrm{A}+$ chry $>0.35$ were from combustion source. Finally, PAHs with $\mathrm{IP} / \mathrm{IP}+\mathrm{BP}<0.2$ were from petroleum origin input, while PAHs with $0.2<\mathrm{IP} / \mathrm{IP}+\mathrm{BP}<0.5$ were mainly from oil combustion, and $\mathrm{IP} / \mathrm{IP}+\mathrm{BP}>0.5$ were typical of the combustion of coal, wood and grassed matter. In this work, none of these ratios can be applied. PAH components such as Fluoranthene, Indo Pyrene have not been found in the coastal lagoon of Grand-Lahou.

The presence of benzo (a) anthracene and benzo (b) fluoranthene in the sediment is a public health problem especially since these pollutants are considered by International Agency for Research on Cancer (IARC) and Environmental Protection Agency (EPAUSA) as a potential carcinogen to humans (Agency for Toxic Substances and Disease Registry, 1995). This is risk to local residents who use the lagoon for several activities (fishing, recreation, transportation...). Pyrene is found in large quantities in the lagoon at any season. This chemical compound is known to be very hydrophobic, low volatility, more recalcitrant to biodegradation than LMWPAHs and therefore persistent in soils and contaminated sediments. It is mutagenic but it is not considered as a carcinogen. Its effects on the ecosystems are relatively poorly known.

The analysis of the presence of HAPs in the Grand-Lahou coastal lagoon showed a clear dominance of high molecular weight (HMW) PAHs (pyrene, Benzo (k) fluoranthene, Benzo (a) pyrene, indeno (1,2,3cd) pyrilène, Benzo $(\mathrm{g}, \mathrm{h}, \mathrm{i})$ pyrilène, Benzo (a) anthracene , Benzo (b) fluoranthene). Low molecular weight (LMW) PAHs was only represented by fluoranthene. The total concentrations of PAHs were between 1.55 and $437.52 \mu \mathrm{g} / \mathrm{g}$ in the dry season. In the rainy season, the total PAHs concentrations varied between 46.35 and $1222.73 \mu \mathrm{g} / \mathrm{g}$. The possible sources of PAHs in the Grand-Lahou lagoon are oil and fuel spills from ships and fishing boats, waste combustion, domestic wastes disposal and especially the production 
of charcoal on the Grand-Lahou lagoon shores.

\section{REFERENCES}

Abe J, Bakayoko S, Bamba SB, Koffi KP. 1993. Morphologie et hydrodynamique à l'embouchure du fleuve Bandama. $J$. Ivoir. Océanol. Limnol., 2: 9-24.

Agency for Toxic Substances and Diseases Registry. 1995. Toxicological Profiles for Polycyclic Aromatic Hydrocarbons $(P A H s)$. US Department of Health and Human Service, Public Health Services: Atlanta, GA.

Baek SO, Field RA. 1991. Aromatic Hydrocarbons: Source, Fate and Behavior. Water Air Soil Pollut., 60: 273300.

Baumard P, Budzinski H, Michon Q, Garrigues P, Burgeot T, Bellocq J. 1998a. Origin and bioavailability of PAHs in the Mediterranean Sea from mussel and sediment records. Estuarine Coastal and Shelf Science, 47: 77-90.

Baumard P, Budzinski H, Garrigues P. 1998b. PAHs in Arcachon Bay, France. Origin and biomonitoring with caged organisms. Mar. Pollut. Bull., 36: 577 - 586.

Bicego MC, Taniguchi S, Yogui GT. 2006. Assessment of contamination by polychlorinated biphenyls and aliphatic and aromatic hydrocarbons in sediment of the Santos and Sao Vicente estuary system, Sao Paulo, Brazil. Mar. Poll. Bull., 52: 1784-832.

Doong RA, Lin YT. 2004. Characterisation and distribution of polycyclic aromatic hydrocarbon contamination in surface sediment and water from Gao-Ping River, Taiwan. Water Res., 38: 1733-1744.

Durand JR, Chantraine JM. 1982. L'environnement climatique des lagunes ivoiriennes. Rev. Hydrobiol. Trop., 15: 85-113.

Eisler R. 1987. Polycyclic aromatic hydrocarbon hazards to fish, wildlife, and in vertebrates: a synoptic review Biological Report 85 (1.11). Contaminant Hazard Reviews Report, 11: 55.
Essumang DK, Adokoh CK, Afriyie J, Mensah E. 2009. Source assessment and analysis of polycyclic aromatic hydrocarbon in the Oblogo waste disposal sites and some water bodies in and around the Accra Metropolis of Ghana. $J$. Water Resour. Protect., 1: 456 - 468.

Girard G, Sircoulon J, Touchebeuf P, Guillaumet JL, Adjanohoun E, Perraud A 1971. Le Milieu Naturel de la Côte d'Ivoire. Mémoire ORSTOM, Paris, 50: $109-155$.

Giuliani S, Sprovieri M, Frignani M, Huu Cu N, Mugnai C, Bellucci LG, Albertazzi S, Romano S, Feo ML, Marsella, E, HoaiNhono D. 2008. Presence and origin of PAH in sediments of nine coastal lagoons in central Vietnam. Marine Pollution Bulletin., 56: 1504-1512.

Hié DJP. 1986. La pêche artisanale maritime. Rapp. Centre. Rech. Océanogr. Abidjan: 77-82.

Juhasz AL, Naidu R. 2000. Bioremediation of high molecular weight polycyclic aromatic hydrocarbons: a review of the microbial degradation of the benzo(a)pyrene. Int. Biodeter. Biodegr., 45: 57 - 88.

Khairy MA, Kolb M, Mostafa AR, EL-Fiky A, Bahadir M. 2009. Risk assessment of $\mathrm{PAH}$ in a Mediterranean semi-enclosed basin affected by human activities (Abu Qir Bay Egypt). J. Hazard Mater., 170: $389-397$.

Karickhoff SW, Brown DS, Scott TA. 1979. Sorption of hydrophobic pollutants on natural sediments: Water Resour Res., 13: 241-248.

Khim JS, Lee KT, Kannan K, Villeneuve DL, Giesy JP, Koh CH. 2001. Trace organic contaminants in sediment and water from Ulsan Bay and its vicinity, Korea. Arch. Environ. Contam. Toxicol., 40: 141-150.

Kouassi AM. 2005. Hydrochimie et qualité des eaux de deux lagunes tropicales de Côte d'Ivoire (Ébrié, Grand-Lahou). Thèse de Doctorat, Université de Cocody, Abidjan, 242 p. 
Lae R. 1982. Premières observations sur la pêche en lagune de Grand-Lahou. DEA Océanographie tropicale (Université de Brest), $30 \mathrm{p}$.

Latimer JS, Quinn JG. 1998. Historical trends and current inputs of hydrophobic organic compounds in an urban estuary: the sedimentary record. Environmental Science and Technology, 30: $623-633$.

Lei A, Lei P, Hu ZL, Wong YS, Fung-Yee N. 2007. Removal of fluoranthene and pyrene by different microalgal species. Bioresour. Technol., 98: 273-280.

Li A, Irwan A, Razak AB, Fan N, Michael F, Gin E, Christensen R. 1998. Polycyclic aromatic hydrocarbons in the sediments of the Milwaukee harbor estuary, Wisconsin, USA. Water, Air and Soil Pollution, 101(1-4): 417 - 434.

Maskaoui K, Zheng T, Hong H, Yu Z, Yuan J, $\mathrm{Hu}$ Z. 2004. Preliminary study on PAH degradation by bacteria from contaminated sediments in Xiamen Western Sea, Fujian, China. Chin. J. Oceanol. Limnol., 22: 431 - 435.

Neff J. 1979. Polycyclic Aromatic Hydrocarbons in the Aquatic Environment Sources, Fates and Biological Effects. Applied Science. Publishers Ltd.: London; 262p.

Nyarko E, Botwe BO, Klubi E. 2011. Polycyclic aromatic hydrocarbons (PAHs) levels in two commercially important fish species from the coastal waters of Ghana and their carcinogenic health risks. West African Journal of Applied Ecology, 9: 53 - 66.

Pavoni B, Mecozzi M, Berto D, Ausili A, Romano E, Amici M, Zharova N, Amato E. 2001. Micropolluants, organic carbon and textural properties in surface sediments in the Moroccan coast. Toxicol. Environ. Chem., 84: 53 - 62.

Semlali A, Chafik A, Talbi M, Budzinski H. 2012. Origin and Distribution of
Polycyclic Aromatic Hydrocarbons in Lagoon Ecosystems of Morocco. The Open Environmental Pollution \& Toxicology Journal, 3 (Suppl 1-M5): 3746.

Soclo HH, Garrigues PH, Ewald M. 2000. Origin of Polycyclic aromatic hydrocarbons (PAHs) in coastal marine sediments: case studies in Cotonou (Benin) and Aquitaine areas. Mar Pollut., 36: $2103-2118$.

Specchiulli A, Renzi R, Perra G, Cilenti L, Scirocco T, Florio M, Focardi S, Breber P, Focardi SP. 2010. Distribution and sources of polycyclic aromatic hydrocarbons (PAHs) in surface sediments of some Italian lagoons exploited for aquaculture and fishing activities International Journal of Environmental Analytical Chemistry, 91 (4): 367-386.

Trabelsi S, Driss MR. 2005. Polycyclic aromatic hydrocarbons in superficial coastal sediments from Bizerte Lagoon, Tunisia. Marine Pollution Bulletin, 50: $344-359$.

Wakeham SG, Schaffner C, Giger W. 1980. Polycyclic aromatichydrocarbons in recent lake sediments of compounds having anthropogenic origins. Geochim Cosmochim Acta, 44: 403-413.

Wang G, Mielke HW, Quach V, Gonzales C, Zhang Q. 2004. Determination of polycyclic aromatic hydrocarbons and trace metals in New Orleans soils and sediments. Soil Sed. Contam., 13: 313327.

Yunker MB, Macdonald RW, Vingarzan R, Mitchell H, Goyette D, Sylvestre. 2002. PAHs in the Fraser river bassin: a critical appraisal of PAH ratios as indicators of PAH source and composition. Org. Geochem., 33: 489-515. 